JERZY GOCKO SDB

Katedra Teologii Moralnej Społecznej KUL

e-mail: Jerzy@Gocko.pl

DOI: https://doi.org/10.18290/rt.20673-13

\title{
WYKAZ PUBLIKACJI TEOLOGICZNOMORALNYCH ZA ROK 2018
}

\section{KSIĄŻKI}

Aborcja w polskich sporach społeczno-prawnych lat 1919-1997, red. M. Kwapiszewska, Ł. Moniuszko, J. Raniszewski, Wydawnictwo Avalon, Kraków 2018.

Adam i Ewa po pigułce: paradoksy rewolucji seksualnej, red. M. Eberstadt, tłum. M. Samborska, Wydawnictwo AA, Kraków 2018.

Aksjologia i etyka polityki, red. T. Buksiński, Wydawnictwo Państwowej Wyższej Szkoły Zawodowej im. Prezydenta Stanisława Wojciechowskiego, Kalisz 2018. Antropologia filozoficzna a antropologia teologiczna Karola Wojtyły - Jana Pawła II: próba opisania relacji, red. K. Wilczek, Wydawnictwo „Scriptum”, Kraków 2018.

BuCZeK ElżBIETA, MiChał JóźWIAK, Eksperymenty na zwierzętach. Czy istnieją „prawa zwierząt”?, Wydawnictwo św. Stanisława BM Archidiecezji Krakowskiej, Kraków 2018.

Bunt mas czy kryzys elit? red. A. Dylus, S. Sowiński, Wydawnictwo TUM Wrocławskiej Księgarni Archidiecezjalnej, Wrocław 2018.

Bynnie z@mienić wolności na pustynię: o formacji do korzystania ze środków społecznego przekazu w duchu chrześcijańskim, red. B. Bąk, M. Kluz, Uniwersytet Papieski Jana Pawła II w Krakowie, Wydawnictwo Naukowe, Kraków 2018.

Cases w perspektywie teologicznomoralnej, red. A. Drożdż, Jedność, Kielce 2018.

Cenić sobie moralność: z wiarą nadzieją i miłością, red. A. Drożdż, Katedra Teologii Moralnej UŚ, Katowice 2018.

Czego księża nie powiedzą Ci o antykoncepcji?, red T. Terlikowski, Wydawnictwo Polskiej Prowincji Dominikanów W drodze, Poznań 2018.

Człowiek, ludzie, międzyludzkie: eseje z nie-Ewangelicznego modelu człowieka, red. L. Nowak, Wydawnictwo Naukowe Semper, Warszawa 2018.

Człowiek, przyroda, moralność, red. J.A. Majcherek, Księgarnia Akademicka, (C) copyrigh, Kraków 2018.

Dobre obyczaje w medycynie, red. K. Szmaglińska, M. Fajler, B. Zapart, Zakład Filozofii i Bioetyki. Katedra Nauk Społecznych i Humanistycznych. Wydział Nauk o Zdrowiu w Katowicach, Śląski Uniwersytet Medyczny, Katowice 2018. 
Dobro i sprawiedliwość w opiece zdrowotnej, red. W. Galewicz, Wydawnictwo Uniwersytetu Jagiellońskiego, Kraków 2018.

Dylematy etyczne w świecie biznesu, red. W. Słomski, Instytut Studiów Międzynarodowych i Edukacji Humanum, Warszawa 2018.

Dyskursy gościnności: etyka współbycia w perspektywie późnej nowoczesności, red. A. Dziadek, M. Glosowitz, D. Kujawa, K. Szopa, A. Angulo, Uniwersytet Śląski, Katowice, Instytut Badań Literackich PAN, Warszawa 2018.

Dzieje miłości, red. M. Skiba. Wydawnictwo Amoryka, Sandomierz 2018.

Ekologia wyzwaniem dla Kościołów chrześcijańskich, red. K. Halkowicz, J.M. Lipniak, Papieski Wydział Teologiczny we Wrocławiu, Wrocław 2018.

Etos: o filozofii i etyce - dla lekarzy, red. J. Sytnik-Czetwertyński, Wydawnictwo Naukowe PWN, Warszawa 2018.

Etyka i biznes: katechizm dla przedsiębiorców, red. A.V. Abela, J.E. Capizzi, tłum. R. Dudała, Wydawnictwo Jedność Language: Polish Original language: English, Jedność, Kielce 2018.

Etyka mediów - utopia czy powinność, red. M. Drożdż, K. Drąg, Biblos, Tarnów 2018.

Etyka solidarności oraz Homo sovieticus, red. J. Tischner, wyd. 3, Wydawnictwo Znak, Kraków 2018.

Etyka środowiskowa w edukacji ekologicznej, red. B. Gola, Oficyna Wydawnicza „Impuls”, Kraków 2018.

Etyka w turystyce, red. M. Zowisło, M. Kazimierczak, Akademia Wychowania Fizycznego im. Bronisława Czecha w Krakowie, Kraków 2018.

Etyka zawodu adwokata: regulamin wykonywania zawodu adwokata: komentarz praktyczny, orzecznictwo, wzory i kazusy, red. W. Bergier, J. Jacyna, wyd. 3, Wydawnictwo C.H. Beck, Warszawa 2018.

Etyka, śmierć i transplantacje, red. P.G. Nowak, Wydawnictwo Uniwersytetu Jagiellońskiego, Kraków 2018.

Filozofia i etyka w szkole, red. A.M. Kaniowski, Wydawnictwo Uniwersytetu Łódzkiego, Łódź 2018.

Filozofia wobec zła: od spekulacji do transgresji [Philosophy and evil: from speculation to transgression], red. M. Drwięga, R. Strzelecki, Wydawnictwo Uniwersytetu Jagiellońskiego, Kraków 2018.

Genderowa rodzina: perspektywa chrześcijańska, red. E. Szwarczyńska, Księgarnia św. Jacka, Katowice 2018.

GierTyCh Wojciech, The Spark of Faith. Understanding the Power of Reaching Out to God, EWTN, Irondale, Alabama 2018.

GIERTYCH WoJCIECH, Wiara a wolność, Wydawnictwo Giertych, Kórnik 2018.

Globalne oblicza wolności, red. J. Zimny, Katolicki Uniwersytet Lubelski Jana Pawła II, Katedra Pedagogiki Katolickiej, Stalowa Wola 2018.

Granice prawoznawstwa wobec etyki, praw człowieka i prawa karnego, red. M. Łaszewska-Hellriegel, M. Kłodawski, Oficyna Wydawnicza Uniwersytetu Zielonogórskiego: Zielona Góra 2018. 
Homo iudicans: sądzenie jako degradacja osoby, red. E. Fiała, Katolicki Uniwersytet Lubelski Jana Pawła II. Katedra Teorii i Antropologii Literatury, Wydawnictwo KUL, Lublin 2018.

Intuicje moralne: o poznaniu dobra i zła, red. A. Szutta, Wydawnictwo Academicon, Lublin 2018.

Karol Wojtyła - Jan Paweł II o człowieku, red. B. Kastelik, A. Krupka, J. Kupczak, Uniwersytet Papieski Jana Pawła II w Krakowie, Kraków 2018.

Karol Wojtyła i Humanae vitae: wkład arcybiskupa krakowskiego i grupy polskich teologów w encyklikę Pawła VI, red. P.S. Gałuszka, tłum. K. Stopa, Muzeum Jana Pawła II i Prymasa Wyszyńskiego, Warszawa 2018.

Katolicka myśl ekonomiczno-społeczna wobec fundamentalnych założeń ekonomii głównego nurtu, red. A. Zadroga, Katolicki Uniwersytet Lubelski Jana Pawła II, Wydział Teologii, Instytut Nauk o Rodzinie i Pracy Socjalnej, Wydawnictwo KUL, Lublin 2018.

Komunikować ludzki etos, red. M. Drożdż, Uniwersytet Papieski Jana Pawła II w Krakowie, Kraków 2018.

Kosche Magdalena M., Życie w społeczeństwie sieci. Teoria Manuela Castellsa a katolicka nauka społeczna, Instytut Wydawniczy PAX, Warszawa 2018.

Kościół ubogich: papież Franciszek i transformacja ortodoksji, red. C. Sedmak, tłum. D. Chabrajska, Instytut Wydawniczy PAX, Wydawnictwo Polskiej Prowincji Dominikanów W drodze, Poznań 2018.

Kształcenie w zakresie etyki dziennikarskiej w kontekście mediów społecznościowych, red. M. Laskowska, Dom Wydawniczy ELIPSA, Warszawa 2018.

Kształcenie, moralność, demokracja: teorie i koncepcje wychowania i kształcenia moralno-etycznego i ich związki z etyką i polityką, Education, morality, democracy: theories and concepts of moral education and their relation to ethics and politics, red. D. Benner, D. Stępkowski, A. von Oettingen, Z. Peng, Wydawnictwo Naukowe Uniwersytetu Kardynała Stefana Wyszyńskiego, Warszawa 2018.

$\mathrm{Ku}$ życiu wartościowemu: idee, koncepcje, praktyki, t. 2. Koncepcje - praktyki, red. W. Danilewicz, J. Nikitorowicz, M. Sobecki, Oficyna Wydawnicza Impuls, Kraków 2018.

$\mathrm{Ku}$ życiu wartościowemu: idee, koncepcje, praktyki, t. 1. Idee - koncepcje, red. M. Czerepaniak-Walczak, J. Madalińska-Michalak, B. Śliwerski, Oficyna Wydawnicza Impuls, Kraków 2018.

KUPCZAK JAROSŁAW, Źródła sporu o Amoris laetitia, W drodze, Poznań 2018.

Media w rodzinie w perspektywie pastoralno-społecznej, red. I. Celary, G. Polok, Wydział Teologiczny Uniwersytetu Śląskiego, Księgarnia św. Jacka, Katowice 2018.

Miłość a życie społeczne, red. S. Partycki, Towarzystwo Naukowe Katolickiego Uniwersytetu Lubelskiego Jana Pawła II, Lublin 2018.

Miłość warta obrączek: jak zbudować małżeństwo na całe życie, red. R. Skrzypczak, wyd. 1, Fundacja Instytut Globalizacji, Gliwice 2018.

Moralność chrześcijańska w zderzeniu z obojetnością religijną, red. W. Pieja, Wydawnictwo Wiesław Pieja, Tarnów 2018. 
Muszala Andrzej, Chcę kontemplować Boga. O. Maria Eugeniusz, Fundacja Pustelnia pl, Kraków 2018.

Muszala ANDRZEJ, Embriologia starożytna, Wydawnictwo Medycyna Praktyczna, Kraków 2018.

Nasz język ojczysty: etyka i estetyka słowa, red. M. Mycawka, R. Mazur, B. Żebrowska, Wydawnictwo Libron, Kraków 2018.

Neuroetyka a Tomasz z Akwinu: o użyteczności myśli średniowiecznej we współczesnych debatach etycznych, red. P. Lichacz, Wydawnictwo IFiS PAN, Warszawa 2018.

Nurty etyki: od starożytności do nowożytności, red. W. Zuziak, Wydawnictwo Naukowe Akademii Ignatianum, Kraków 2018.

Oblicza wojny, red. M.M. Baran, Arbitror, Warszawa 2018.

Obowiązek podatkowy jako powinność moralna: w świetle katolickiej nauki społecznej, red. P. Król, Duszpasterstwo Przedsiębiorców i Pracodawców Talent, Kraków 2018.

Odpowiedzialność zawodowa lekarza, red. A. Daniluk-Jarmoniuk, Wydawnictwo Uniwersytetu Marii-Curie Skłodowskiej, Lublin 2018.

Osoba i media w prawdzie i uczciwości, red. M. Drożdż, Wydawnictwo Petrus, Kraków 2018.

Osoba jako byt i norma w filozofii kardynała Karola Wojtyły, red. H. Tomasik, Wydawnictwo Diecezji Radomskiej AVE, Radom 2018.

Piękno nietolerancji: spojrzenie na moralność i poprawność polityczną Bożymi oczami, red. J. McDowell, S. McDowell, tłum. S.Wacławik, Oficyna Wydawnicza „Vocatio”, Warszawa 2018.

Podstawy teologii moralnej, red. A. Olczyk, Częstochowskie Wydawnictwo Archidiecezjalne Regina Poloniae, Częstochowa 2018.

Polityka przyjazna człowiekowi, red. J. Mazur, Wydawnictwo Paulinianum, Częstochowa 2018.

Polityka: zmierzch czy odrodzenie?, red. K. Korab, Ośrodek Myśli Politycznej, Kraków 2018.

Poza dobrem i złem, Z genealogii moralności, red. F. Nietzsche, tłum. P. Pieniążek, Officyna, Łódź 2018.

Prawa człowieka a wyzwania bioetyczne związane $\mathrm{z}$ nowymi technologiami, red. A. Białek, M. Wróblewski, Biuro Rzecznika Praw Obywatelskich, Warszawa 2018.

Prawa człowieka, red. W. Brzozowski, A. Krzywoń, M. Wiącek, Wolters Kluwer, Warszawa 2018.

Prawa poczętego pacjenta: zagadnienia interdyscyplinarne, teoria i praktyka, red. B. Kmieciak, Instytut na rzecz Kultury Prawnej Ordo Iuris, Warszawa 2018.

Prawda, poufność, autonomia - problemy informacji w etyce medycznej, red. W. Galewicz, Towarzystwo Autorów i Wydawców Prac Naukowych UNIVERSITAS, Kraków 2018.

Prawo naturalne a ład polityczny, red. Z. Stawrowski, wyd. 2, Instytut Myśli Józefa Tischnera, Kraków 2018. 
Prawo, zwyczaj, moralność jako fundamenty porządku społecznego: praca zbiorowa, red. A. Tarczyński, Wydawnictwo Uniwersytetu Kazimierza Wielkiego, Bydgoszcz 2018.

Problem kryzysu cnoty wstydliwości: w świetle nauczania Kościoła i wybranej literatury teologicznomoralnej, red. A. Strama, Uniwersytet Papieski Jana Pawła II w Krakowie, Wydawnictwo Naukowe, Kraków 2018.

Prusak MaŁgorzata, Bioetyka dla farmaceuty, Wydawnictwo Bernardinum, Pelplin 2018.

Przywództwo, etyka, polityka, red. E.M. Marciniak, J. Szczupaczyński, M. Hartliński, L. Nowak, J.G. Otto, F. Pierzchalski, S. Sowiński, J. Szczupaczyński, J. Ziółkowski, K. Zuba, A. Zygo, Instytut Nauk Politycznych. Wydział Nauk Politycznych i Studiów Międzynarodowych, Uniwersytet Warszawski, Dom Wydawniczy Elipsa, Warszawa 2018.

Pulchrum et communicatio: księga jubileuszowa profesora Karola Klauzy, red. A. Wójciszyn-Wasil, M.J. Gondek, D. Wadowski, Wydawnictwo KUL, Lublin 2018.

Rachunek sumienia: czy żyję Dekalogiem?, red. W. Głusiec, Wydawnictwo Archidiecezji Lubelskiej Gaudium, Lublin 2018.

RATZINGER JOSEPH / BENEDYKT XVI, Uwolnić wolność: wiara a polityka w trzecim tysiącleciu, red. P. Azzaro, C. Granados, red. pol. K. Góźdz, M. Górecka, Katolicki Uniwersytet Lubelski Jana Pawła II, Fundacja Rozwoju KUL, Lublin 2018.

Realizm i analiza: zarys metafizycznego rozumienia świata rzeczy i osób, red. J. Tupikowski, Wydawnictwo SALWATOR, Kraków 2018.

Religia wobec wyzwań współczesności z perspektywy nauk społecznych, red. I. Borowik, S. Grotowska, Wydawnictwo Naukowe Scholar, Warszawa 2018.

Rozumowanie moralne: osoba, rozwój, wychowanie, red. U. Gruca-Miąsik, Wydawnictwo Uniwersytetu Rzeszowskiego, Rzeszów 2018.

Rzetelne dziennikarstwo: aksjologia i deontologia, red. T. Kononiuk, Uniwersytet Warszawski, Wydział Dziennikarstwa, Informacji i Bibliologii, Oficyna Wydawnicza ASPRA-JR, Warszawa 2018.

Selekcja genetyczna w prokreacji medycznie wspomaganej: etyczne i prawne kryteria, red. M. Soniewicka, Wolters Kluwer, Warszawa 2018.

Skryty wymiar etyczności w myśli Martina Heideggera, red. P. Korobczak, Oficyna Wydawnicza Arboretum, Wrocław 2018.

Społeczne nauczanie Kościoła Prawosławnego, red. J. Kostiuczuk, Polski Autokefaliczny Kościół Prawosławny, Warszawska Metropolia Prawosławna, Wydawnictwo Language: Polish Summary language: English, Warszawska Metropolia Prawosławna, Warszawa 2018.

Spór wokół interpretacji Amoris laetitia, red. A. Pryba, Uniwersytet im. Adama Mickiewicza, Wydział Teologiczny, Poznań 2018.

Sprawności moralne jako przedmiot refleksji wychowawczej, red. I. Jazukiewicz, E. Rojewska, Wydawnictwo Naukowe Uniwersytetu Szczecińskiego, Szczecin 2018. 
Standardy etyczne w prawie: próba systematyzacji, red. K.A. Brożek, Oficyna Naukowa: Wydział Prawa i Administracji Uniwersytetu Warszawskiego, Warszawa 2018.

Śmierć mózgu: czy istnieją granice organodawstwa, red. R. Breul, przekł. J. Jurczyński, Rafael, Kraków 2018.

Świat wartości w wychowaniu i edukacji, red. U. Szuścik, Wydawnictwo Uniwersytetu Śląskiego, Katowice 2018.

Teologiczna, filozoficzna i naukowa wizja człowieka, red. P. Moskal, Katolicki Uniwersytet Lubelski Jana Pawła II. Wydawnictwo KUL, Lublin 2018.

U źródeł idei praw człowieka: kształtowanie prawnych i filozoficznych podstaw koncepcji praw człowieka, red. M. Merkwa, B. Paprocka, Wydawnictwo Uniwersytetu Marii Curie-Skłodowskiej, Lublin 2018.

Uczestniczyć w losie Drugiego: rozmowy o etyce, Kościele i świecie, red. I. Dudkiewicz, A. Szostek, Biblioteka „Więzi”, Warszawa 2018.

Ulepszanie człowieka: fikcja czy rzeczywistość?: argumenty, krytyka, poszukiwanie płaszczyzny dialogu, red. G. Hołub, Wydawnictwo Naukowe Akademii Ignatianum, Kraków 2018.

Umysł moralny: jak powstają oceny moralne?, red. A. Macko, Wydawnictwo Poltext, Warszawa 2018.

Uwolnienie z ciężaru winy po grzechu aborcji, red. W. Kowalska, Wydawnictwo AA; Inicjatywa Ewangelizacyjna Wejdźmy na Szczyt, Kraków 2018.

Vita activa: wybór tekstów z „Moraliów” o życiu czynnym, Św. Grzegorz Wielki, red. T. Konsek, Tyniec Wydawnictwo Benedyktynów, Kraków 2018.

Vita contemplativa: wybór tekstów z „Moraliów” o życiu kontemplacyjnym, Św. Grzegorz Wielki, red. T. Konsek, Tyniec Wydawnictwo Benedyktynów, Kraków 2018.

W kręgu zagadnień bioetycznych i ekologicznych, red. A. Derdziuk, Towarzystwo Naukowe Katolickiego Uniwersytetu Lubelskiego Jana Pawła II, Lublin 2018.

W obronie ludzkiej godności i solidarności: Erich Fromm i Isaiah Berlin ku nowym filozoficznym podstawom państwa i prawa, red. M. Kilanowski, Wydawnictwo Naukowe Uniwersytetu Mikołaja Kopernika, Toruń 2018.

Warto uprawiać seks małżeński, bo pozamałżeński zawsze pozostanie bezowocnym ugorem, czyli o pielęgnowaniu sfery płciowości i życiu w czystości seksualnej, red. J. Pulikowski, wyd. 2, IW Jerozolima, Poznań 2018.

Wezwani do życia miłosierdziem: wielowymiarowe spojrzenie na kwestię miłosierdzia, red. J. Kotkowski, Uniwersytet im. Adama Mickiewicza w Poznaniu. Wydział Teologiczny, Poznań 2018.

Wojtyła Karol. Katolicka etyka społeczna, red. G.J. Beyer, A. Lekka-Kowalik, A.M. Wierzbicki, Wydawnictwo KUL - Wydział Filozofii KUL - Ośrodek Badań nad Myślą Jana Pawła II - Instytut Jana Pawła II KUL, Lublin 2018.

Wolność: wieczne wyzwanie. Tom okolicznościowy poświęcony profesor Anieli Dylus w siedemdziesiątą rocznicę urodzin, red. B. Rydliński, S. Sowiński, R. Zenderowski, Wydawnictwo Naukowe UKSW - Fundacja Konrada Adenauera w Polsce, Warszawa 2018. 
Wprowadzenie do etyki zawodowej: etyka zawodowa pracownika socjalnego [Introduction to professional ethics: professional ethics of a social worker], red. K. Kalka, Wydawnictwo Państwowej Wyższej Szkoły Zawodowej im. Stanisława Staszica, Piła 2018.

Wprowadzenie w studium teologii moralnej fundamentalnej: materiały pomocnicze, red. M. Tomaszewski, H. Stompor, Wydawnictwo Naukowe Collegium Bobolanum, Warszawa 2018.

Wychowanie a sens życia: człowiek w obliczu dylematów egzystencjalnych, red. J. Spętana, Oficyna Wydawnicza Impuls, Kraków 2018.

Wyzwania i zagrożenia bioetyczne XXI wieku, red. W. Sinkiewicz, R. Grabowski, Komisja Bioetyczna BIL - Bydgoska Izba Lekarska - Dom Wydawniczy Margrafsen, Bydgoszcz 2018.

Źródła sporu o Amoris laetitia, red. J. Kupczak, Wydawnictwo Polskiej Prowincji Dominikanów W Drodze, Poznań 2018.

\section{ARTYKUŁY}

ANDRYSZCZAK PIOTR, Większość źródłem prawdy o dobru?, „Analecta Cracoviensia” 50(2018), s. 163-172.

BALÁK RENÉ, Neverending History of the use of Vaccines derived from aborted Infants. Part II: Moral evaluation in the light of the principle of double effect and encyclicals „Veritatis splendor” and „Evangelium vitae”, „Roczniki Teologiczne" 65(2018), z. 3, s. 101-116.

BORTKIEWICZ PAWEe, Kreatywne sumienie w Amoris laetitia?, „Teologia i Moralność” 13(2018), nr 23, s. 61-75.

BORTKIEWICZ PAWEŁ, W biologię rodzenia wpisana jest genealogia osoby. W stronę sedna sporu o Humanae vitae, „Teologia i Moralność” 13(2018), nr 24, s. 29-43.

BRUSIŁO JERZY, Braterstwo ludzi i zwierząt według św. Franciszka z Asyżu. W poszukiwaniu dobrostanu zwierząt, w: Dobrostan zwierząt. Różne perspektywy, red. H. Mamzer, WN Katedra, Poznań 2018, s. 161-179.

ChŁopowiec MichaŁ, Pokutna peregrinatio we wczesnym średniowieczu, „Vox Patrum" 38(2018), t. 69, s. 83-103.

Chojnacki Grzegorz, „Oto Partia: siła ludów i sumienie” - komunistyczna wizja (de)formacji sumienia, „Studia Paradyskie” 28(2018), s. 145-157.

ChoJnacki Grzegorz, 1 concetto di fare teologia per il cardinale Newman, w: Immaginario e realta: Percorsi della religione, a cura di Angelo Rella e Sebastiano Valerio, Alberobello: AGA Arti Grafiche 2018, s. 209-215.

CHOJNACKI GRZEGORZ, Troska o pacjentów w fazie umierania i stanie wegetatywnym w niemieckim dialogu ekumenicznym, ,Studia Oecumenica” 18(2018), s. 281-296.

Chrzanowski Grzegorz, Chrześcijański sens cierpienia: Max Scheler i Jan Paweł II, w: Na ścieżkach pragnienia: księga jubileuszowa profesora Karola Tarnowskiego, Wydawnictwo Znak, Kraków 2018, s. 111-130.

CZABAŃSKi AdAM, MARIAŃSKi JANUSZ, Problematyka samobójstw w ujęciu Marii Jarosz, „Teologia i Moralność” 13(2018), nr 24, s. 225-241. 
CZACHOROWSKi MAREK, Pojęcie prawdy we współczesnej etyce prawniczej, „Teologia i Moralność" 13(2018), nr 24, s. 197-209.

DERDZIUK ANDRZEJ, Charakterystyczne cechy duchowości franciszkańsko-kapucyńskiej w życiu i posłudze ojca Hieronima Ryby, w: Hieronim Ryba OFMCap (1850-1927), red. R. Rabka, Wydawnictwo Serafin, Kraków 2018, s. 49-79.

DERDZIUK ANDRZEJ, Droga zawierzenia Jacka Krawczyka 1966-1991, „Śląskie Studia Teologiczno-Historyczne" 51(2018), nr 1, s. 157-170.

DERDZIUK ANDRZEJ, Znamiona świętości w życiu Jacka Krawczyka, „Roczniki Teologiczne" 65(2018), z. 3, s. 63-80.

DROŻDŻ MiCHAŁ, Świadomość działania jako podstawa etycznego wartościowania, „Studia Socialia Cracoviensia” 10(2018), nr 2(19), s. 11-20.

FICOŃ MARTA, Antydemoniczny charakter sakramentu pokuty i pojednania, „Analecta Cracoviensia" 50(2018), s. 23-51.

GĘBKA MikoŁaJ, (Nie)dopuszczalne ograniczanie liczby potomstwa? Refleksja o aborcji w świadomości społecznej Polaków (na podstawie badań opinii publicznej), „Teologia i Moralność” 13(2018), nr 24, s. 147-167.

GIERTYCH WojCIECH, ,The Creation of the Human Soul”, Doctor Communis, „Pontificia Academia Sancti Thomae Aquinatis" 1(2018), s. 201-218.

GIERTYCH WoJCIECH, „Pondus virgulae. L'importanza di una virgula nell'Humanae vitae", w: Incontri di Studio, Roma, Penitenzieria Apostolica 8 V 2018, s. 3-28.

Gocko JerzY, Methodological Status of the Social Doctrine of the Church before the Second Vatican Council, „Seminare” 39(2018), nr 4, s. 57-64.

Gocko JERZY, Wkład Marie-Dominique Chenu i Paula Ricœura w odnowę nauki społecznej Kościoła w okresie wczesnej recepcji Soboru Watykańskiego II, „Roczniki Teologiczne” 65(2018), z. 3, s. 35-51.

GóRKa BogusŁaw, Dekalog jako kryterium cywilizacyjne, w: Dialogi o kulturze, kultury dialogu: Jubileusz Profesora Hieronima Chojnackiego, Wydawnictwo Uniwersytetu Gdańskiego, Gdańsk 2018, s. 49-55.

GRYZ KRZYSZTOF, Prawo stopniowości w posynodalnych adhortacjach o rodzinie Familiaris consortio i Amoris laetitia, „Teologia i Moralność" 13(2018), nr 23, s. 153-179.

KIMSZA RADOSŁAW, Teomaterialismo della liturgia e la divinizazione della persona umana secondo Pavel Evdokimov, „Roczniki Teologiczne” 65(2018), z. 3, s. 51-62.

KLUZ MAREK, Chrystocentryzm wiary w Lumen fidei papieża Franciszka, „Analecta Cracoviensia" 50(2018), s. 79-99.

KŁOS-SKRZYPCZAK ALEKSANDRA, Wstępna recepcja adhortacji Amoris laetitia przez Konferencję Amerykańskich Biskupów Katolickich, „Teologia i Moralność” 13(2018), nr 23, s. 209-223.

KUMÓR MAREK, Etyka małżeńska we współczesnym nauczaniu Kościoła w perspektywie encykliki Humanae vitae, ,Społeczeństwo i Rodzina” 2(2018), s. 88-101.

KUPCZAK JAROSŁAW, Kasper Walter i Ratzinger Joseph o komunii dla osób rozwiedzionych i w powtórnych związkach, ,Teologia i Moralność” 13(2018), nr 23, s. 39-60.

KWIATKOWSKI DARIUSZ, Święty Józef jako patron i opiekun życia w kazaniach biskupa Stanisława Napierały, „Teologia i Moralność” 13(2018), nr 24, s. 267-282. 
MACHINEK MARIAn, Czy potrzebna nam jest dzisiaj sztuka umierania?, w: Jest nadzieja, bo jest życie wieczne, red. B. Kulig, W. Pałęcki, Katolicki Uniwersytet Lubelski, Lublin 2018, s. 161-186.

MACHINEK MARIAN, Przesłanie Humanae vitae z perspektywy pięćdziesiątej rocznicy ogłoszenia encykliki, „Teologia i Moralność” 13(2018), nr 24, s. 13-27.

Melina Livio, Interpretacje Gaudium et spes i recepcja Humanae vitae, ,Teologia i Moralność" 13(2018), nr 24, s. 67-81.

Melina Livio, Wyzwania Amoris laetitia dla teologa moralisty, „Teologia i Moralność” 13(2018), nr 23, s. 25-38.

MORCINIEC PIOTR, Diskriminierung von Senioren - Fakten über und Wege für das würdige altern, „Family Forum” 8(2018), s. 53-69.

Mosorov Volodymir, Skobel StanisŁaw, Analiza moralna uczynków Starców na przykładzie wybranych apoftegmatów Ojców Pustyni, „Łódzkie Studia Teologiczne" 27(2018), nr 3, s. 251-262.

MuSZALA ANDRZEJ, Sposoby rozwiązywania małżeńskich kwestii „nieregularnych” w Kościele starożytnym i wczesnośredniowiecznym, „Teologia i Moralność” 13(2018), nr 1(23), s. 141-151.

NAWROT JANUSZ, Biblijne fundamenty encykliki Humanae vitae, „Teologia i Moralność" 13(2018), nr 24, s. 45-65.

NIEWIADOMSKI KRZYSZTOF, Wierzący rodzic wobec problemu SSA swojego dziecka. Katolicka perspektywa moralno-pastoralna, „Ateneum Kapłańskie” 2018, t. 171, nr 2, s. 329-344.

Nowosad SŁAwomir, Christian Martrydom Never Expires: Some Theological and Ethical Aspects of Obedience usque ad sanguinem. „Seminare. Poszukiwania Naukowe" 39(2018), nr 4, s. 21-30.

Nowosad SŁAWOMIR, O nieodzowności teologii w kulturze i nauce, w: Polonia Restituta 1918-2018. Kultura i tożsamość, Ministerstwo Nauki i Szkolnictwa Wyższego - Katolicki Uniwersytet Lubelski Jana Pawła II, Warszawa-Lublin 2018, s. 18-21.

NowoSAD SŁAWOMIR, Od antropologicznego błędu do antropologicznej rewolucji, „Studia Leopoliensia” 11(2018), s. 25-36.

NowosAD SŁAWOMIR, Transhumanizm - próba analizy i oceny, „Studia Leopoliensia” 11(2018), s. 177-199.

Nowosad SŁAWOMIR, Zarys etyki buddyjskiej, „Roczniki Teologiczne” 65(2018), z. 3, s. 21-33.

OLBRYCHT KATARZYNA, Współczesne uwarunkowania kulturowe wychowania w duchu encykliki Pawła VI Humanae vitae, ,Teologia i Moralność” 13(2018), nr 24, s. $113-127$.

OlCZYK MACIEJ, „Zapominanie o Bogu, a nie jego wielbienie, rodzi przemoc”. Nadzieja dla Europy w świetle przemówień Jana Pawła II i Franciszka w parlamencie europejskim, w: Dialog wielokulturowości i prawda, red. H. Czakowska, M. Kuciński, Kujawsko-Pomorska Szkoła Wyższa w Bydgoszczy, Bydgoszcz 2018, s. 253-271. 
OlCZYK MACIEJ, Edukacja seksualna jako wychowanie do miłości. Niezmienne pryncypia i nowe wyzwania w świetle Amoris laetitia, „Teologia i Moralność” 13(2018), nr 23, s. 125-139.

OlCZYK MACIEJ, Prawda (o) płci - odkrywana czy tworzona? Antropologia integralna w konfrontacji z ideologią gender, „Teologia i Moralność” 13(2018), nr 24, s. $183-195$.

OLCZYK MACIEJ, Wokół duszpasterskich wytycznych Konferencji Episkopatu Polski do Adhortacji Amoris laetitia, „Studia Bydgoskie” 12(2018), s. 153-162.

OLEJNIK KRZYSZTOF, Rola wiary w kształtowaniu postawy katolickiej według Augusta kardynała Hlonda, „Teologia i Moralność” 13(2018), nr 24, s. 253-266.

OlsZANOwski PIOTR, Poszukiwanie prawdy moralnej w życiu i twórczości Johna Henry’ego Newmana, „Teologia i Moralność” 13(2018), nr 24, s. 169-182.

OLSZANOWSKI PIOTR, Problematyka rozumienia porządku moralnego w perspektywie miłosierdzia rozpoznawana przez dobrze ukształtowane sumienie w adhortacji apostolskiej Amoris laetitia, ,Teologia i Moralność” 13(2018), nr 23, s. 181-194.

PIELAK PIOTR, Nauczanie teologii moralnej w Seminarium Diecezji Siedleckiej 18182018, „Teologiczne Studia Siedleckie” 15(2018), s. 175-214.

PLICH ROBERT, Legalistyczna neutralizacja nauki o czynach wewnętrznie złych i absolutnych zakazach moralnych w adhortacji Amoris laetitia, „Teologia i Moralność" 13(2018), nr 23, s. 89-123.

PodZIELny JANusz, Christliche Gestalt des Patriotismus aus der Sicht der Polnischen Bischofskonferenz, „Śląskie Studia Historyczno-Teologiczne” 51(2018), z. 2, s. 426-434.

PODZIELNY JANUSZ, Ewangelickie oraz katolickie nauczanie o antykoncepcji jako sporny obszar dialogu ekumenicznego, „Studia Oecumenica” 18(2018), s. 317-332.

PODZIELNY JANUSZ, Poglądy gospodarcze Marcina Lutra, w: Reformacja protestancka 1517 roku. Spory o dziedzictwo, red. C. Lipiński, W. Brylla, Quaestio, Wrocław 2018, s. 109-118.

POlaK MieczysŁaw, Między ograniczonością ludzką a prawem Bożym. Duszpasterstwo miłosierdzia w sytuacjach nieregularnych, ,Teologia i Moralność” 13(2018), nr 23, s. 195-207.

SARMiento Augusto, Humanae vitae: prorocza encyklika, „Teologia i Moralność” 13(2018), nr 24, s. 83-111.

SCHOCKENHOFF EBERHARD, Zerwanie z tradycją czy niezbędny rozwój? Dwa sposoby rozumienia posynodalnej adhortacji Amoris laetitia, „Teologia i Moralność” 13(2018), nr 23, s. 11-23.

Skobel StanisŁaw, Fedorowicz Judyta, Od tożsamości do wspólnoty. Polska na tle relacji międzynarodowych, ,Społeczeństwo. Studia, prace badawcze i dokumenty z zakresu nauki społecznej Kościoła” 24(2018), nr 2, s. 101-125.

SKOBEL StAnisŁaw, Les problèmes de l'homme avec la liberté. Vision chretienne de notre liberté, „La società. Rivista scientifica de la dottrina sociale della Chiesa” 26(2018), nr 3, s. 161-173.

Skobel StANiSŁaW, Nadzieja dzisiaj. Współczesne ujęcia teologiczne nadziei: między ,już” a ,jeszcze nie”, w: Религия и общество 12, red. О. Дьяченко, В.В. Старостеико, МГУ имени А.А. Кулешова, Могилев 2018, s. 295-298. 
Skobel StanisŁaw, Nowość encykliki Benedykta XVI Caritas in veritate wobec ciągłości nauczania społecznego Kościoła, „Społeczeństwo. Studia, prace badawcze i dokumenty z zakresu nauki społecznej Kościoła” 24(2018), nr 1, s. 79-90.

Skobel StAnisŁaW, Poznawać coraz pełniej i chętniej nauczanie społeczne Kościoła, „Społeczeństwo. Studia, prace badawcze i dokumenty z zakresu nauki społecznej Kościoła” 24(2018), nr 1, s. 10-17.

SKOBEL StAniSŁaw, Święta miłości kochanej ojczyzny..." - od wolności do prawdziwej miłości ojczyzny, ,Społeczeństwo. Studia, prace badawcze i dokumenty z zakresu nauki społecznej Kościoła" 24(2018), nr 2, s. 10-15.

SMYKOwSKI KRZYSZTOF, Czy chrześcijanie mogą „narzucać” swoje prawa ludziom mającym inny światopogląd. Uwagi na marginesie debaty społecznej w Polsce, „Sympozjum” 22(2018), nr 2, s. 199-209.

SMYKOWSKI KRZYSZTOF, Działania szkół wyższych i instytucji finansujących naukę na rzecz etyki badań z udziałem ludzi, w: Crux ave spes unica. Księga jubileuszowa dedykowana Księdzu Biskupowi dr. Janowi Tyrawie z okazji 70 rocznicy urodzin oraz 30 rocznicy sakry biskupiej, red. G. Barth, Pejzaż, Bydgoszcz 2018, s. $885-890$.

SMYKOWSKI KRZYSZTOF, Ecological Conversion and Its Pastoral Ministry as a Stipulation for True Reconciliation, „Rocznik Teologii Katolickiej” 17(2018), nr 1, s. 7-17.

SMYKOWSKI KRZYSZTOF, Propozycje zmian w przepisach dotyczących ochrony zwierząt. Próba oceny z perspektywy teologii moralnej, „Roczniki Teologiczne” 65(2018), z. 3, s. 119-132.

SMYKOWSKI KRZYSZTOF, Theological-Moral Foundations, w: Catholic Family Ministry. The Scientific Reflection and the Practical Ministry of the Church, red. J. Goleń, R. Kamiński, G. Pyźlak, Wydawnictwo KUL, Lublin 2018, s. 74-81.

SMYKOWSKI KRZYSZTOF, Wniebowzięcie Najświętszej Maryi Panny w posoborowej liturgii Kościoła, w: Uwierzyliśmy miłości... Księga pamiątkowa XV Inauguracji Roku Akademickiego w Wyższym Seminarium Duchownym Diecezji Bydgoskiej ofiarowana bp. Janowi Tyrawie, red. M. Puziak, Wyższe Seminarium Duchowne Diecezji Bydgoskiej, Bydgoszcz 2018, s. 137-146.

SMYKOWSKI KRZYSZTOF, Współczesny rozwój technologii medycznych wyzwaniem dla etyki, w: Dialog wielokulturowości i prawda, red. H. Czakowska, M. Kuciński, Wydawnictwo KPSW, Bydgoszcz 2018 s. 329-336.

SMYKOWSKI KRZYSZTOF, Zwierzęta w publikacjach polskich myślicieli katolickich I połowy XX wieku, „Medycyna Weterynaryjna” 75(2019), nr 1, s. 59-62.

Sobkowiak Sebastian, Prawda w Internecie. Czy katolickie portale internetowe manipulują informacjami?, „Teologia i Moralność” 13(2018), nr 24, s. 211-223.

StelmaCh DAwID, Trudne pojednanie w Rwandzie. Refleksje wokół świadectwa ks. Janviera Gasore'a SAC, „Teologia i Moralność” 13(2018), nr 24, s. 243-252. SurmiaK WoJCIECH, Celibat a intymność, „Roczniki Teologiczne” 65(2018), z. 3, S. 131-147.

SzCZODRY MARCIN, Bioetyka katolicka i bioetyka laicka - dialog czy konfrontacja?, „Studia Paradyskie” 28(2018), s. 103-115. 
SzCZODRY MARCIN, Światowe Dni Młodzieży jako wydarzenie kształtujące sprawności moralne młodego pokolenia, w: Sprawności moralne jako przedmiot refleksji wychowawczej, red. I. Jazukiewicz, E. Rojewska, Wydawnictwo Naukowe Uniwersytetu Szczecińskiego, Szczecin 2018, s. 133-149.

TRON ANDREI, Oblubieńcza jedność Chrystusa i Kościoła a sakrament małżeństwa w adhortacji apostolskiej Amoris laetitia, ,Teologia i Moralność” 13(2018), nr 23, s. 77-88.

WIŚNIOWSKA KAROLINA, Etyka bezstronności Petera Singera jako filozoficzna podstawa dla etycznego konsumeryzmu?, „Logos Ethos” 47(2018), nr 1, s. 199-220.

WLAZŁo SYLWIA, Patriotyzm jako jedna z dróg do świętości w świetle życia i pism św. Rafała Kalinowskiego, „Teologia i Moralność” 13(2018), nr 24 s. 283-298.

WoJTKun JAROSŁAW, Dramat uzależnienia młodego pokolenia i drogi prewencji, „Rocznik Naukowy Duszpasterstwa Nauczycieli” 2(2018), s. 239-251.

WojtKun JarosŁaw, The Natural and Supernatural Dimensions of Priestly Formation, „Rocznik Teologii Katolickiej” 17(2018), nr 1, s. 33-48.

WoJTKun JAROSŁAW, W przededniu październikowego Synodu Biskupów o młodzieży. Omówienie dokumentu przygotowawczego, „Zeszyty Formacji Katechetów” 4(2018), s. 17-24.

WróBel JózeF, Bioethical Foundations, w: Catholic Family Ministry. The Scientific Reflection and the Practical Ministry of the Church, red. J. Goleń, R. Kamiński, G. Pyźlak, Wydawnictwo KUL, Lublin 2018, s. 121-140.

WRÓBEL JÓzEF, Preselekcja płci dziecka z perspektywy bioetyki katolickiej, ,Roczniki Teologiczne" 65(2018), z. 3, s. 81-99.

ZABIELSKI JózeF, Jezus Chrystus Królem i Panem narodu polskiego i państwa, w: Teologiczne podstawy kultu Chrystusa jako Króla, red. J. Grzywaczewski, Wydawnictwo Uniwersytetu Stefana Kardynała Wyszyńskiego, Warszawa 2018.

ZABIELSKI JózEF, „Przyczyna naszej radości” w zaraniu niepodległości (1981-2021), „Wiadomości Kościelne Archidiecezji Białostockiej” 46(2018), nr 4, s. 181-183.

ZABIELSKI JÓZEF, „Pocieszycielka strapionych” w okresie niewoli narodowej, „Wiadomości Kościelne Archidiecezji Białostockiej” 46(2018), nr 4, s. 177-180.

ZABIELSKI JóZEF, Blessed Michael Sopoćko: A Closer Look at the Mystery of Divine Mercy, „Rocznik Teologii Katolickiej” 17(2018), nr 2, s. 53-67.

ZABIELSKI JóZEF, Bł. Ks. Jerzy Popiełuszko - obrońca wiary, prawdy i wolności, w: „Религия и общество - 12. Сборник научных статей”, red. В.В. Страрстенко, О.В. Дъяченко, Могилев 2018, s. 299-301.

ZABIELSKI JóZEF, Degradacja życia religijno-moralnego jako zagrożenie ładu społeczno-cywilizacyjnego, „Rocznik Teologii Katolickiej” 17(2018), nr 3, s. 335-349.

ZABIELSKI JóZEF, Moralno-pastoralne wyzwania wobec współczesnej rodziny w świetle Adhortacji Amoris laetitia, „Collectanea Theologica” 3(2018), s. 137-147.

ZABIELSKI JÓZEF, Pomoc osobom starzejącym się jako wyzwanie współczesnej rodziny, w: Osoby starsze w rodzinie i Kościele, red. P. Ochotny, Warszawa 2018, s. 61-75.

ZABIELSKI JÓZEF, Rehabilitacja moralna narodu polskiego jako normatyw patriotyzmu w nauczaniu Stefana kardynała Wyszyńskiego, „Społeczeństwo” 2(2018), s. 85-100. 
ZABIELSKI JÓZEF, Religijno-moralne odrodzenie narodu polskiego jako ratowanie ojczyzny w posłudze pasterskiej kardynała Stefana Wyszyńskiego, w: Stefan Wyszyński wobec oporu społecznego i opozycji 1945-1981, red. E.K. Czaczkowska, Warszawa 2018, s. 251-263.

ZABIELSKI JóZEF, Świętowanie niedzieli jako moralno-społeczne wyzwanie współczesności, „Collectanea Theologica” 88(2018), nr 1, s. 193-201.

ZABIELSKI JóZEF, Wartościowanie cierpienia jako wyzwanie terapeutyczne, w: W drodze do brzegu życia, t. XVI, red. E. Krajewska-Kułak, C. Łukaszuk, J. Lewko, W. Kułak, Uniwersytet Medyczny w Białymstoku, Wydział Nauk o Zdrowiu, Białystok 2018, s. 172-181.

ZADYKOWICZ TADEUSZ, The Contemporary Sociocultural Context of Family Ministry, w: Catholic Family Ministry. The Scientific Reflection an the Practical Ministry of the Church, red. J. Goleń, R. Kamiński, G. Pyźlak, Wydawnictwo KUL, Lublin 2018, s. 187-200.

Zadykowicz TAdeusz, The Ethics of Tourism: Determining the Fundamental Moral Issue, Part I. „Rocznik Teologii Katolickiej” 17(2018), nr 1, s. 49-61.

ZADYKowicz TADEUSZ, The Ethics of Tourism: Determining the Fundamental Moral Issue, Part II. „Rocznik Teologii Katolickiej” 17(2018), nr 3, s. 351-363.

ZADYKOWICZ TADEUSZ, Wiedza, umiejętności i kompetencje społeczne jako efekty kształcenia w zakresie teologii moralnej, „Roczniki Teologiczne” 65(2018), z. 3, s. 5-19.

Zazula Monika, Kaleciak Szczepan, Muszala AndrzeJ, Niska jakość opieki wielodyscyplinarnej, oferowanej w Polsce osobom z zespołem Downa, w: Fizykodiagnostyka i rehabilitacja w medycynie i stomatologii - zespół Downa, red. T. Matthews-Brzozowska, E. Mojs, Uniwersytet Medyczny im. Karola Marcinkowskiego, Poznań 2018, s. 145-154.

Zazula Monika, Kaleciak Szczepan, Szymoniak Krzysztof, Dąbek KatarzyNA, Muszala AndRZEJ, Problemy medyczne osób z trisomią 21 według raportu „Problemy rodzin dzieci z zespołem Downa w Polsce - stan na przełomie 2017 i 2018 roku”, „Medycyna Praktyczna” 11(2018), s. 116-120.

ZIMNIEWICZ NATALIA, Wpływ zjawisk ekonomicznych na zaburzenia procesów informowania o działaniu i skuteczności antykoncepcji hormonalnej, „Teologia i Moralność" 13(2018), nr 24, s. 129-145. 